\title{
The Effectiveness of Metro Vancouver’s Green Bin Program
}

\author{
Alexander M. Lui ${ }^{1}$, Helen Heacock ${ }^{2}$
}

\section{Abstract}

\section{Background and Aims}

Metro Vancouver is implementing a disposal ban on all food scraps from entering the landfills and incinerators by the year 2015. In order to prepare the city's residents, a food scraps recycling program, known as the Green Bin Program, was initiated in 2013 for all single family households. The aim of this research project was to measure public knowledge and awareness of the program across various demographics and collect data on the general opinion of it.

\section{Methods}

An online survey was created using SurveyMonkey, a survey generating website, and distributed online via Facebook and e-mail. The results from these surveys were analyzed using NCSS software to determine statistical significance via a chi-squared analysis with alpha (a) $=0.05$.

\section{Results}

There were a total of 70 respondents. Of these, $68 \%$ of the respondents indicated that the Green Bin Program should stay the way it currently is without any further changes. $8 \%$ of the respondents were in favour of stopping the program and the remaining $24 \%$ indicated that the program needed some modifications such as more education/promotional material, implementing the program into apartment complexes and more garbage pickup days to prevent pest and odor problems. Age category, location of residence, and educational background were analyzed against other variables in the survey that tested the knowledge and usefulness of the Green Bin Program. Looking at these 3 variables in relation to knowledge: there was no association between location of residence, age, and educational background, with knowledge of what could go into the green bin $(p=0.76, p=0.53, p=0.33$, respectively). These same 3 demographic variables were also analyzed against frequency of food scraps recycling and there was a positive association between age and frequency $(\mathrm{p}=0.037)$, indicating that respondents aged 19-29 were recycled food scraps more than respondents over the age of 29. However, there was no association between location/education and frequency ( $p=0.32$ and $\mathrm{p}=0.10$, respectively). Non demographic variables were also analyzed, such as determining if household size and garbage bin size had an effect on frequency of food scraps recycling: household size did not have a significant association ( $\mathrm{p}=0.70)$ while garbage bin size did have a positive association ( $\mathrm{p}=0.025$ ), showing that residences with smaller garbage bins were more likely to recycle their food scraps.

\section{Conclusion}

These results indicated limited knowledge of the Green Bin program and pinpointed deterrents (mostly pests and odors) from participating in it. Environmental Health Officers' involvement would be important as educators to emphasize that certain organic wastes (like pet fecal matter) should not go into the green bin as they create health hazards. EHOs can also collaborate with the municipality to promote the program. Several participants reported recycling their food scraps; as a result, the Metro Vancouver Green Bin Program has achieved some of its aims in creating a greener and more sustainable city.

Keywords: Food Scraps, Recycling, Green Bin, Metro Vancouver, Garbage

\footnotetext{
${ }^{1}$ Lead Author, B. Tech Student, School of Health Sciences, British Columbia Institute of Technology, 3700 Willingdon Ave, Burnaby, BC V5G 3H2

${ }^{2}$ Supervisor, School of Health Sciences, British Columbia Institute of Technology, 3700 WIIlingdon Ave, Burnaby, BC V5G 3H2
} 


\section{$\underline{\text { Introduction }}$}

As Metro Vancouver's population continues to climb towards 3 million (Statistics Canada, 2012), the amount of solid waste being produced is also reaching proportionately high levels. In an effort to divert all of this waste from being deposited into Vancouver's landfill, the city has created the “Zero Waste Action Plan” (City of Vancouver, 2011). The main goal of this plan is to steadily decrease the volume of recyclable and/or compostable materials from entering the landfill or incinerator, as these practices can increase greenhouse gases in the atmosphere and require the consumption of more raw materials (Bridges et al., 2000). One vital aspect of this plan is the Green Bin (or food scraps recycling) program.

The food scraps recycling program requires residents living in single family houses (and duplexes) to place all food scraps in their yard trimmings/green bin and not in their black garbage bin (City of Vancouver, 2011). This program has been initiated in cities all over Metro Vancouver. One of the city's long term goals of the Green Bin Program is to prepare metro Vancouver for a ban, effective 2015, on disposing any food scraps/yard trimmings with regular garbage. Consequently, it is important to determine how effective, thus far, the program has been in getting residents to recycle their food scraps.

\section{Public Health Significance}

Waste management can present several issues that may affect public health. From hazardous materials and toxic gases to pest management, it is important that all waste disposal is done properly and efficiently. With more recycling and less disposal, there are both benefits and problems that may arise. This literature review will address both facets and provide a basis for this study.

\section{Vancouver Landfills and their capacity}

The most common method of disposing solid waste is to bury it within a landfill, which is a site or large area of land that has been excavated and designed to receive waste (Ministry of Environment, 1993). However, while the waste is often compacted before it is placed into the pit, diminishing space is still an ongoing issue.

Currently, Metro Vancouver's solid waste goes to either the Vancouver landfill (located in the city of Delta) or the Cache Creek landfill; both are sanitary landfills, designed to serve populations of 5000 people or more (City of Vancouver, 2011). According to the 2012 Vancouver Landfill Annual Report, a total of 1,444, 959 tonnes of waste was received at the dump site during that year (Vancouver Landfill Annual Report, 2012). This number represented an increase of almost 150,000 tonnes from the previous year's amount. Taking this into account, an operating agreement between Vancouver and Delta was drafted to permit the use of the landfill until the year 2037; when the agreement expires, the site will need to be reassessed for capacity.
In 2011, the Cache Creek landfill received approximately 279,000 tonnes of waste and was found to be near full capacity (Cache Creek Annual Report, 2011). The Cache Creek Annual Report states that by 2016, the landfill will have reached full capacity and must be closed. As a temporary fix, the BC Ministry of Environment approved a 42 hectare extension, providing it with approximately 25 more years of shelf-life (Belkorp, 2010). After this 25 year period extension is over, there are no current plans to prolong the use of this landfill any further. As these two major waste dump sites continue to fill up, metro Vancouver has begun to find alternative ways of managing municipal garbage.

\section{Reducing Greenhouse Gas emissions from landfills}

Another aspect of landfills that is a concern for public health is the gas emissions. Unlike glass or plastic waste in the landfill, organic waste decomposes when it is put into the ground. When the food scraps are broken down in an environment with little to no oxygen, methane is produced. This gas has a warming effect that is 23 times stronger than carbon dioxide (Walsh, 2008). Methane emissions from garbage on a global scale are estimated to be around 70 million tonnes a year, a number that some believe is a major contributing factor to global warming (Walsh, 2008).

\section{Burnaby's Waste To Energy Facility}

Apart from landfills, metro Vancouver also diverts municipal waste to a Waste-to-energy (WTE) facility located in Burnaby (Metro Vancouver, 2012). This facility uses incineration to treat the solid waste they receive. Each year, they burn approximately 285,000 tonnes of garbage at temperatures greater than 1000 degrees Celsius (Metro Vancouver, 2012). The heat produced is used to power a turbo generator to generate electricity; a by-product of this procedure is the emission of flue gas (gas from a pipe) and production of bottom ash and fly ash (Metro Vancouver, 2012).

Incinerators are controversial because of the substances released as a result of burning the garbage. In particular, the flue gas can contain air particulates, heavy metals, methane, and other organic compounds like dioxins and furans, all of which can present serious health hazards upon exposure (Candela et al., 2013). For example, the ultrafine particulate emissions (nanoparticles) have been associated with asthma, Type 2 diabetes, immune system dysfunctions, and multiple sclerosis (Nelson, 2010).

Incinerating facilities do take measures to filter and clean the incineration emissions; however, the bottom ash that is produced from incineration needs to be disposed of in a landfill and this can present some issues. For example, in September of 2013, cadmium (a known carcinogen) was detected in the Vancouver landfill at twice its allowable limit (Sinosky, 2013). The source of the cadmium was determined to be the bottom ash produced from Burnaby's WTE facility. As a result, Metro Vancouver had to pay for the removal of 
the toxin while dealing with concerned public citizens. Environmentalist David Suzuki has spoken about the dangers of incineration and claims that “...through education and regulation, we can reduce obvious sources [of waste] and divert more compostable, recyclable and reusable materials away from the dump." (David Suzuki Foundation, 2013)

\section{Metro Vancouver's Zero Waste Action Plan}

Vancouver has implemented a "zero waste strategy" plan in an attempt to divert all recyclable and compostable materials away from the landfill and incinerator. The plan has goals to reach $70 \%$ diversion of all waste from entering the landfill by the year 2015 and $80 \%$ by the year 2020 (Yepsen, 2011). They have three main objectives to help them accomplish this: the green bin program (which will be described later), green demolition, and extended producer responsibility (EPR) programs. Green demolition refers to reducing the amount of demolition waste entering the landfill and ensuring more recyclable/reusable materials are being used at these demolition sites. EPR programs place an emphasis on the producer's responsibility for making their product more environmentally friendly or recyclable.

As well, the Zero Waste Strategy lists several priority actions (see table 1); of these, the only one that has been completely initiated and currently being carried out is the collection of food scraps and compostable materials from single family households. For this reason, the focus of this study will be on this objective of the zero waste strategy.

Table 1: Metro Vancouver's Zero Waste Strategy Objectives

\begin{tabular}{lc}
\hline Priority action & $\begin{array}{c}\% \\
\text { Completed } \\
\text { June 2013 }\end{array}$ \\
\hline $\begin{array}{l}\text { Collect all compostables from single-family } \\
\text { homes }\end{array}$ & $100 \%$ \\
$\begin{array}{l}\text { Develop education and enforcement } \\
\text { programs to keep recyclables out of the }\end{array}$ & $5 \%$ \\
$\begin{array}{l}\text { waste stream: Enforced by the } \\
\text { municipalities (not the health authorities) }\end{array}$ & \\
$\begin{array}{l}\text { Develop multi-family food scraps diversion } \\
\text { strategy } \\
\text { Advocate for more Extended Producer } \\
\text { Responsibility programs for packaging }\end{array}$ & $40 \%$ \\
\hline
\end{tabular}

\section{The Green Bin Program}

A major part of Vancouver's plan to divert waste away from the landfill is the recycling of food scraps with yard waste and sending it to a composting facility located in Richmond (Metro Vancouver, 2012). This has become known as the green bin program, named because of the color of the yard waste receptacle receiving these compostable materials. In a 2011 report by the City of Vancouver, it was estimated that 129,000 tonnes of food scraps were entering the landfill from commercial, multi family, and single family sectors (with the single family sector contributing 26,000 tonnes) (City of Vancouver, 2011).

Instead of adding food scraps to their garbage bin, Vancouver residents can place them with their yard waste for weekly pickup. In April 2010, Vancouver piloted this program with 100, 000 single family customers and measured the response (Standing Committee on City Services and Budgets, 2010). Their findings (after a year) showed about 660 tonnes of food scraps being diverted away from the landfill, or roughly only $2.5 \%$ of the total amount of food scraps that year. They achieved only $12 \%$ household participation despite a widespread mass marketing campaign. As a result, Vancouver decided to change their approach into a social marketing campaign instead.

Before the start date of the program, each single family household/duplex within a participating municipality was given a small green container by the city; directions were to place it in the kitchen to collect daily food scraps which would then be placed into the large green bin outside (Metro Vancouver, 2012). Along with each container, an informational pamphlet was handed out describing the program and how to recycle food scraps with yard waste. Amongst the information, a list of recyclable food items was included (Metro Vancouver, 2013):

- $\quad$ Raw and cooked fruits and vegetables

- Tea bags and coffee grounds

- Meat

- Fish

- Bones

- Pasta

- Grains

- Bread

- Dairy products

- $\quad$ Food-soiled paper such as used pizza boxes, paper towels and napkins

After the initiation of this program, all of Metro Vancouver's municipalities participated. However, after the findings from the 2010 pilot program, some cities in Metro Vancouver took additional action and switched to having their garbage pickup weekly to every other week. The municipalities of Surrey, New Westminster, Pitt Meadows, Port Coquitlam, Port Moody, and Vancouver, changed their garbage pickup schedule while allowing yard waste/food scraps to be picked up weekly (See Appendix A). According to the Metro Vancouver waste collection website, if every resident living in a home recycled their food scraps, there would be 2800 less trucks going to the landfill each year (Metro Vancouver, 2013). By implementing this program now, Metro Vancouver is preparing for a city-wide ban on the disposal of all food scraps by the year 2015.

\section{Pests, Odours, and other Issues}

As a result of placing food scraps and organic materials into a bin without being contained in a plastic bag, there is potential for rodents, maggots, and other pests to be attracted. The smell of rotting garbage can also present an 
issue. The City of Surrey provides some tips to counteract some of these problems, such as lining the bin with old newspapers and cardboard, keeping the bin in a shady area, and washing the bin with mild soap and water weekly. Other options include freezing meat and bones before placing them in the green bin (City of Surrey, 2013).

Another issue is enforcing the program and getting residents to participate. Zotos et al. (2013) believe that the “...decentralisation of waste management issues to local authorities without a parallel substantial budgetary and capacity support” is a main cause for implementation problems and delays. This claim was supported by the implementation delays and differences in the program start dates between different municipalities within metro Vancouver, which was partially attributed to the decentralization of waste management to each district. For example, Surrey began the program in October 2012, while Vancouver did not start until May 1, 2013.

\section{After Recycling}

The food scraps from Metro Vancouver's Green Bin program are sent to a 30 acre composting facility in Richmond. Once there, the piles of scraps are covered in bark and wood ash which acts as a biofilter to remove odours (Tucker, 2010). The scraps are then put through an anaerobic digester machine; the methane from this process is used to produce electricity (2010). After this, a rich organic compost is produced. This compost can be used for a variety of purposes, such as landscaping, gardening, or highway applications (Curbside Foodscraps Collection program, 2008).

\section{Relevance to Environmental Health Officers}

While this program is relatively new and does not yet have a defined role for health inspectors nor any specific legislation to enforce Vancouver's Zero Waste Action Plan, EHOs are nonetheless involved in the inspection of any waste disposal processes from a human health standpoint. Facilities, such as any restaurants or food service establishments, that choose to participate in the Green Bin Program can be inspected and checked for proper disposal of food scraps into the green bin. The Ontario Ministry of Labour lists several responsibilities of EHOs with regards to waste management, one of which may be applicable to food scraps disposal as well: Prevention of exposure to infectious materials in the waste that could cause illness (Ontario Ministry of Labour, 2013). An example may include fecal matter or pet waste, which may often be mistaken as acceptable to dispose of in an organics recycling bin. EHOs may respond to complaints that facilities or residents are placing the fecal waste into their Green Bins, and thus, may create a health hazard. EHOs may also get involved with education regarding pest or odor problems associated with the green bin. This may include educating the public on washing their bins out regularly with soap and water, as well as explaining the health hazards (such as pest harbourage) that may occur if they do not clean their bins.

\section{Purpose of Study/Research Question}

The purpose of this study was to determine overall awareness of Metro Vancouver's green bin program and how successful it was in getting single family households/duplexes to recycle their food scraps. It also investigated factors that may affect why certain households participate in the program.

\section{Materials and Methods}

Materials used include the survey generating program “Survey Monkey”, Number Cruncher for Statistical Systems (NCSS), Microsoft Excel, Email, and Social Media platforms (primarily Facebook).

\section{Description of standard method}

The primary tool used in this study was a survey, or self administered questionnaire, generated with the online program “Survey Monkey”. In order to obtain relevant and easily analyzable information, all survey questions were close-ended and carefully selected to provide clear and distinct options from which participants could choose. All questions were input into the Survey Monkey online program and a questionnaire was generated (Survey Monkey, 2013). The use of a survey for this study was to predict characteristics of a large population by investigating the behaviour of a smaller subset that could be representative of the attitudes of Metro Vancouver residents with regards to the Green Bin (food scraps recycling) Program (Metro Vancouver, 2012). Surveys were distributed to contacts of the researcher via email and social media (Facebook), who then distributed the survey to their contacts and so forth. This "snowball” effect was used to achieve a wide and diverse sample size.

\section{Reliability and Validity of measures}

Reliability is concerned with the consistency of the survey, including the degree to which the questions asked can elicit the same type of information each time they are used under the same conditions (Kramer et al, 2009).The reliability of this survey was determined by its repeatability amongst each respondent. For this questionnaire, only one version was made in order to provide each respondent with the same options. As well, the survey consisted of close-ended questions where respondents were provided with a specific set of options to choose from. In order to maintain consistency, this survey was only administered electronically (via email or social networking sites). To increase reliability for future applications of this study, more questions should be added to the survey; the more factors that are measured will result in a more reliable measurement tool.

Validity, or the overall accuracy, of this survey was another measure that was taken into account (Leedy et al, 2001). External validity, or the extent to which the results can be extrapolated to a larger population, was a crucial aspect of the inclusion criteria for this survey. By choosing 
to include residents living in the Greater Vancouver Regional District (GVRD) despite slight differences in each district's food scraps recycling program, results of the survey can be generalized to represent the target population of Metro Vancouver. Internal validity was taken into account through random assignment of the surveys amongst contacts on Facebook and other social media contacts. In order to increase validity, it was important to try and reach as many people as possible from different locations within Metro Vancouver by having contacts send this survey out to their contacts and continue this trend. As mentioned previously, the snowball effect helped to strengthen external validity by providing a more accurate representation of the city's large population. However, after the survey was administered, it was noted that respondents had not been asked to answer truthfully on the consent form. This may have decreased the internal validity of the survey if the respondents chose to provide any false answers.

The scope of this project is similar to a previous study conducted by Truong, M (2010), whose research involved conducting a survey to gauge public awareness regarding Vancouver's food scrap recycling program. Based on his questionnaire and the responses he received, this study repeated similar questions regarding demographics and overall awareness of the Green Bin Program, while building upon his results; new questions were added to determine residents' level of participation in the program.

\section{Inclusion and exclusion criteria}

Any metro Vancouver residents over the age of 18, living in single family households or duplexes, and able to comprehend and write English, were encouraged to participate. Cities were listed and the respondent was given the choice of selecting one, or "other" if none applied. Both genders and all ethnic backgrounds were also included. Exclusion criteria consisted of those not living in the Metro Vancouver/GVRD region (or who clicked “do not know" as area of residence) and those living in multi-family households, such as apartments and condos.

\section{Ethical Considerations}

While creating the survey, it was important to consider issues relating to ethics. Beneficence, or "protection from harm”, was ensured by disclosing a cover letter and consent form explaining the purpose of the study and allowing all respondents to know that minimal risk would be involved if they chose to participate in this study (Heacock et al, 2013). Another important aspect of ethical consideration was autonomy, or “informed consent”. In order to inform participants that this survey was completely voluntary and that their confidentiality would be maintained, the consent form must have been read and agreed upon by clicking a button which indicated, "Yes, I understand the terms and agree to participate”.

\section{Pilot Studies}

A pilot study was conducted prior to the widespread distribution of the survey. The pilot consisted of sending the survey to five contacts of the researcher, and having each of those contacts send it to at least one of their contacts.

Questions from the pilot study were identical to those in the finished survey, and were used to gauge participant response and overall satisfaction with the method used.

\section{Statistical Analysis And Results}

\section{Description of data}

The scale of response data was a combination of multichotomous nominal and multichotomous ordinal. The nominal data consisted of mostly demographic questions, ranging from determining location of residence to ethnic background. Ordinal data that involved categories of ranking included the frequency of food scraps recycling, the age category of the respondent, amongst other data.

\section{Descriptive statistics:}

The descriptive statistics used for this study included percentages. Survey monkey, Microsoft Excel, and NCSS were all used to input descriptive statistical information, including data related to demographics such as age, ethnicity, etc. Out of 70 respondents, $71 \%$ were between the ages of $19-29$, while the other $29 \%$ were aged 30 or over. $75 \%$ of respondents owned the residence they lived in, which mostly likely meant that the respondents were living with their family that owned the property (given that the majority of respondents were under the age of 29). Areas of residence were grouped into two main categories: those with garbage pickup every week and those with garbage pickup every other week (this was done for analysis purposes: see results), where $72 \%$ of respondents lived in areas with garbage pickup every other week (ie. Vancouver, North Vancouver, New Westminster, Port Coquitlam, Port Moody, and Surrey) while the remaining 28\% lived in areas with weekly garbage pickup (Richmond, Delta, Langley, Burnaby, Coquitlam). Respondents were questioned on household size, with $46 \%$ living in household of 3 people or less.

One of the knowledge questions asked whether pet waste (amongst other organic materials) could be placed in the green bin (it is not allowed). 63\% of respondents answered this question incorrectly and believed that pet waste was acceptable in a food scraps recycling bin. Another knowledge question assessed whether people knew that food scraps disposal into the garbage bin would be banned by the year 2015; 62\% of respondents knew this while 38\% did not. Frequency of food scraps recycling was measured; $51 \%$ of respondents recycled all the time, $30 \%$ recycled food scraps sometimes, and the other $19 \%$ never recycled. Of those who indicated they only recycle sometimes or not at all, 56\% indicated that the main deterrent was odours and/or pests. With regards to garbage bin size, $51 \%$ had the default bin size of 180L while the remaining 49\% either had a bigger bin size or did not know how big their bin was. 
Finally, 68\% of the respondents indicated that the Green Bin Program should stay the way it currently is without any further changes, $8 \%$ of the respondents were in favour of stopping the program and the remaining $24 \%$ indicated that the program needed some modifications such as more education/promotional material, implementing the program into apartment complexes and more garbage pickup days to prevent pest and odour problems.

\section{Inferential Statistics}

The statistical analysis tool used was the chi-square test. This particular test was used to determine whether there was a relationship between the outcomes in two or more groups (Plackett, 1983). For example, is there an association between the frequency of food scraps recycling and location of residence? To determine whether there was some association, the chi-square test was conducted to either reject or not reject the null hypothesis (Ho) by comparing one distribution/result observed with another. These events considered must be mutually exclusive and have total probability (Chernoff et al, 1954). The following is the formula for Pearson's Chi-square test:

$$
\begin{gathered}
\chi^{2}=\sum_{i=1}^{n} \frac{\left(O_{i}-E_{i}\right)^{2}}{E_{i}} \\
\chi^{2}=\text { Pearson's cumulative test statistic, which } \\
\text { asymptotically approaches a } \chi^{2} \text { distribution } \\
O_{i=\text { an observed frequency; }} \\
E_{i=\text { an expected (theoretical) frequency, asserted }} \\
\text { by the null hypothesis; } \\
n=\text { the number of cells in the table. }
\end{gathered}
$$

For this survey, there were several outcomes measured and compared using the chi-square analysis test. The following table lists the null hypotheses tested and whether they were accepted or rejected based on their p value. ( see appendix for complete run through of their analysis through NCSS)

\section{Statistical Package used}

The program NCSS (Number Cruncher for Statistical Systems, 2013) was used to tabulate responses and create a chi square analysis of the data. The program stated whether or not the null hypothesis was rejected. A $p=0.05$ value was selected as the cut-off; if $\mathrm{p}<0.05$, then the results showed statistical significance and the null hypothesis (Ho) was rejected and an association between two groups could be concluded (NCSS, 2013).

\section{Statistical Analysis and interpretation of results}

The following demographic variables were chosen: Age, Location, Educational Background. These 3 variables were analyzed against two key questions that relate to awareness and effectives of the Green Bin Program: a question testing the respondent's knowledge (Question 10: True or False, Pet waste can be put into the Green Bin. The answer was False), and a question on how frequent they recycle their food scraps. See Table 2 below for results of the analysis done on certain variables.

\section{Alpha/Beta Errors}

A type 1 error, or alpha error, occurs when the null hypothesis is wrongly rejected. Based on the results of this study, alpha errors were of concern between age group and frequency of food scraps recycling $(p=0.037)$ and between garbage bin size and frequency of food scraps recycling $(p=0.025)$. These $p$ values are greater than 0.01 and less than 0.05 , so this may indicate only a weak association between these variables or that there is not enough data to support a positive link. A type II error, or beta error, occurs when the statistical test is not significant, which means that after chisquare analysis, there was failure to reject the null hypothesis. This lack of a significant association was found in the hypothesis between city/township of residence and frequency of food scraps recycling $(\mathrm{p}=0.10)$, where the $\mathrm{p}$ value was greater than 0.05 but less than or equal to 0.1 . Therefore, a researcher should cautious when incorrectly concluding that the null hypothesis is true when a statistical test was not significant. Instead, the researcher should consider the test inconclusive. This result means that test was inconclusive and no data from this comparison can be extrapolated to the larger population. In order to minimize this type II error, a larger sample size could be included. 
Table 2: Results of Chi Squared Analysis

\begin{tabular}{|c|c|}
\hline Null (Ho) and Alternate (Ha) Hypothesis & Accept or Reject Null Hypothesis (Ho) \\
\hline $\begin{array}{l}\text { Ho: There is no association between age group and } \\
\text { knowledge of the green bin program. } \\
\text { Ha: There is an association between age group and } \\
\text { knowledge of the green bin program. }\end{array}$ & $\begin{array}{l}\mathrm{P}=0.76 \\
\text { Fail to Reject Ho, there was a strong indication of no } \\
\text { statistically significant association between age group } \\
\text { and knowledge of the green bin program. }\end{array}$ \\
\hline $\begin{array}{l}\text { Ho: There is no association between educational } \\
\text { background and knowledge of the green bin program } \\
\text { Ha: There is an association between educational } \\
\text { background and knowledge of the green bin program. }\end{array}$ & $\begin{array}{l}\mathrm{P}=0.33 \\
\text { Fail to reject Ho, there is no statistically significant } \\
\text { association between educational background and } \\
\text { knowledge of the green bin program }\end{array}$ \\
\hline $\begin{array}{l}\text { Ho: There is no association between city/township of } \\
\text { residence and knowledge of the green bin program. } \\
\text { Ha: There is an association between city/township of } \\
\text { residence and knowledge of the green bin program. }\end{array}$ & $\begin{array}{l}\mathrm{P}=0.53 \\
\text { Fail to reject Ho, there is no statistically significant } \\
\text { association between city of residence and knowledge of } \\
\text { the green bin program. }\end{array}$ \\
\hline $\begin{array}{l}\text { Ho: There is no association between age group and } \\
\text { frequency of food scraps recycling. } \\
\text { Ha: There is an association between age group and } \\
\text { frequency of food scraps recycling. }\end{array}$ & $\begin{array}{l}\mathrm{P}=0.037 \\
\text { Reject Ho, there is a statistically significant association } \\
\text { between age group and frequency of food scraps } \\
\text { recycling, with possible alpha error as } \mathrm{p}>0.01 \text { but }<0.05 \text {. }\end{array}$ \\
\hline $\begin{array}{l}\text { Ho: There is no association between educational } \\
\text { background and frequency of food scraps recycling. } \\
\text { Ha: There is an association educational background and } \\
\text { frequency of food scraps recycling. }\end{array}$ & $\begin{array}{l}\mathrm{P}=0.32 \\
\text { Fail to reject Ho, there is no statistically significant } \\
\text { association between educational background and } \\
\text { frequency of food scraps recycling. }\end{array}$ \\
\hline $\begin{array}{l}\text { Ho: There is no association between city/township of } \\
\text { residence and frequency of food scraps recycling. } \\
\text { Ha: There is an association between city/township of } \\
\text { residence and frequency of food scraps recycling. }\end{array}$ & $\begin{array}{l}\mathrm{P}=0.10 \\
\text { Fail to reject Ho, there is no statistical significance } \\
\text { between city/township of residence and frequency of } \\
\text { food scraps recycling. }\end{array}$ \\
\hline
\end{tabular}

The following non demographic variables were also analyzed: household size (number of people living in household) and garbage bin size. They were measured against frequency of food scraps recycling to determine if living with more people or having a bigger garbage bin was related to how often the person recycled their food scraps.

\begin{tabular}{|l|l|}
\hline $\begin{array}{l}\text { Ho: There is no association between household size and } \\
\text { frequency of food scraps recycling. }\end{array}$ & $\begin{array}{l}\mathrm{P}=0.70 \\
\text { Fail to reject Ho, there is no statistically significant association } \\
\text { between household size and frequency of food scraps recycling. }\end{array}$ \\
$\begin{array}{l}\text { Ha: There is an association between household size and } \\
\text { frequency of food scraps recycling. }\end{array}$ & $\begin{array}{l}\mathrm{P}=0.025 \\
\text { Reject Ho, there is a statistically significant association } \\
\text { between garbage bin size and frequency of food scraps } \\
\text { frecycling. }\end{array}$ \\
$\begin{array}{l}\text { Ha: There is no association between garbage bin size and } \\
\text { frequency of food scraps recycling. }\end{array}$ & \begin{tabular}{l} 
rect scraps recycling. \\
\hline
\end{tabular}
\end{tabular}




\section{Discussion}

As demonstrated by the results, some chi squared pairings showed statistical significance while others did not. One analysis that showed significance linked age group and frequency of recycling food ban scraps. The results showed that the majority of respondents (aged 19-29) were more likely to recycle food scraps more often than older age groups ( $\mathrm{p}=0.037$ ). However, this result may be biased due to a large portion of respondents being a part of this age group to begin with. Possible reasons for this positive association may include the fact that the Green Bin Program is still very new, so many of these younger respondents are more likely to adopt new environmentally friendly initiatives than older people.

The other positive association indicated that respondents with the default size garbage bin (180L) were more likely to recycle their food scraps than those with a larger bin $(\mathrm{p}=0.025)$. An explanation for this result may be that with smaller garbage bin sizes, households need to find a means to prevent their garbage bins from overflowing. Through the green bin program, they are now able to divert all food wastes into a separate bin and reduce the amount of garbage being placed into their 180L garbage bin.

Conversely, residents with large bin sizes, often bigger than the default 180L size, were less likely to recycle their food scraps. Reasons for this may include the convenience of simply putting everything into one bin given that they have enough space for all household waste. Another possible explanation can be linked to the pests and odors issue associated with food scraps. With a garbage bin, residents can put all of their waste into plastic bags and seal in the odors and create an anaerobic environment that limits spoilage organism growth. However, with the green bin, food scraps often just placed loosely into newspaper or other biodegradable materials that are porous and lead to potential pest issues. One solution is to actively promote solutions to prevent this, such as the City Of Surrey's informational guide that instructs residents to freeze food scraps before placing them into the bin. While larger garbage bins may be the easier option for some residents than food scraps recycling, the landfills receiving the garbagt are reaching full capacity, which may soon dictate whether disposing of food scraps into the garbage is still a viable option (Vancouver Landfill Annual Report, 2012).

Most demographic variables analyzed against the knowledge and frequency variables resulted in insignificant findings. These results showed that there was no link between age, educational background and city/township of residence with knowledge of the green bin program. This may point to a lack of overall promotion/awareness of the program, since majority of respondents did not know that pet waste was not allowed into the green bin. Some of the respondents who answered this question correctly mentioned in the feedback section that they had pets, which would explain their awareness of what cannot go into the green bin.
To advocate for more widespread awareness on this topic, EHOs may be able to get involved in this aspect and let the public know that pet waste can create a health hazard if placed in green bins with regular food waste, where none of the organic materials are contained in plastic bags. There was also no link between location of residence and educational background with frequency of food scraps recycling. This may indicate that even areas that only receive garbage pickup every other week are no less likely to recycle their food scraps than areas that have weekly garbage pickup. This would mean that areas with weekly pickup may be able to switch to alternating weekly pickup without any impact on overall food scraps recycling, but with the added benefit of saving the city's resources, money, and time.

As mentioned earlier, Metro Vancouver's Zero Waste Action Plan seeks to divert all waste from entering the landfill by $70 \%$ in the year 2015 . Based on this study, $81 \%$ of respondents recycle their food scraps. This means that food scraps recycling is widely practiced and residents know the program exists; whether this translates to a $70 \%$ waste diversion rate remains to be seen.

Looking at a previous study conducted by Mike Truong, only 53 out of 207 of the respondents from his study knew about the green bin program. This study was conducted before the program was implemented. In comparison, this survey did not ask respondents whether they knew what the Green Bin Program was. Instead, it measured awareness of the program through more specific variables, such as what items could be placed in the bin amongst other aspects that have already been mentioned.

\section{Recommendations}

The main recommendation based on this survey's findings is to increase knowledge of the program itself. Residents may be recycling or using their green bin, but they may not be using it in the correct manner. Majority of respondents did not know what could be placed into the green bin, while only $60 \%$ knew that food scraps was going to be banned from disposal bins in the year 2015. Informational guides should be sent every few months to remind residents what is important to know about their green bin and why they should use it. EHOs should also start getting involved by providing information on health authority websites on the health hazards associated with placing fecal waste into organics bins and the overall importance of using the green bin program with regards to solid waste management, an area of public health. Also, because pests and odors were mentioned as deterrents to recycling food scraps, EHOs can advocate for different green bins than the ones currently available. There should be some thought put into creating a green bin that eliminates pest and odor problems; an example would be to provide biodegradable plastic bags that can be placed into the green bin and do not harm the environment. 


\section{Limitations}

The main limitation was the population size of this study. As only 70 respondents were reached, with some choosing to skip certain questions, the results were extrapolated from a very small sample size. Time was a limitation for the survey, as only a 2 month subscription to SurveyMonkey was purchased. All answers were collected and analyzed within this period. Budget was another limitation, as the survey subscription required most of the money provided by BCIT. This meant that there was no leftover budget for gas to do in-person surveys. Limited resources were also a limitation. Attempts were made to reach out to the City of Vancouver to have feedback on the survey as well as to see if they could send it out; unfortunately, the city did not respond to any requests. The contact list available was also very limited. The survey was sent to several people through Facebook and Email, but after they had filled the survey out, they did not send the survey out further to their own contacts. Combined, all of these aspects became limitations in preventing this study for reaching further and providing a more concrete sample size to base the findings on.

\section{Future Research}

Future studies can look at how the program has changed with the soon-to-be effective food scraps disposal ban in 2015, as well as EHO involvement in education and advocating of different green bins that prevent odor/pest issues. Perhaps the area of solid waste management may become a specialized area for EHOs in the future; similar to what has currently happened with the Health Built Environments Program of public health. Another interesting area that can be looked into is whether this program becomes implemented in apartment buildings/condos/multifamily residences. Since there are many of these apartment complexes in metro Vancouver, implementing this program in these residences may help the city to reach or possibly exceed their waste diversion targets.

\section{Conclusions}

Metro Vancouver's Green Bin Program is in use in cities all around the Greater Vancouver Regional District. However, its use and effectiveness is variable in each region.

Knowledge of the program is spotty at best, and comments from residents for improvements mainly are linked to odor and pest problems that result from having food scrap bins in the first place. Due to the upcoming food scraps disposal ban, it is even more important now that residents become familiar with food scraps recycling and become a proactive citizen in helping Metro Vancouver become more sustainable, as well as ecologically and environmentally friendly.

\section{Acknowledgements}

Special acknowledgements to British Columbia Institute of Technology Environmental Health Department for allocating a budget for this research project and to Helen Heacock and Bobby Sidhu for organizing and providing guidance on this project.

\section{Competing Interest}

The authors declare that they have no competing interests

\section{References}

Belkorp. (2010). Cache Creek Landfill: key facts and figures. Retrieved from:

http://www.belkorp.ca/CCLF_overview_May2010.pdf

Bridges, O., Bridges, J.W., Potter, J.F. (2000). A generic comparison of the airborne risks to human health from landfill and incinerator disposal of municipal solid waste. The environmentalist. 20 (4): 325-334

Cache Creek Annual Landfill Report. (2011). Retrieved from:

https://cachecreek.civicweb.net/Documents/DocumentDispla y.aspx?ID=659

Candela, S., Ranzi, A., Bonvicini, L., Baldacchini, F., Marzaroli, P., Evangelista, A., Luberto, F., Carretta, E., Angelini, P., Sterrantino, A.F., Broccoli S., Cordioli M., Ancona C., Forastiere, F. (2013). Air pollution from incinerators and reproductive outcomes: a multisite study. Europe PubMed Central. 24(6):863-870

Chernoff, H., Lehmann, E. L. (1954). The Use of Maximum Likelihood Estimates in tests for goodness of fit. The Annals of Mathematical Statistics 25 (3): 579-586.

City of Surrey. (2013). Organics Green Cart. Retrieved from: http://www.surrey.ca/city-services/4555.aspx

City of Vancouver. (2011). Food Scraps program. Retrieved from: http://vancouver.ca/green-vancouver/food-scrapsprogram.aspx

Curbside Food Scraps Collection Program. (2008). BioCycle, 49(4), 14-16.

Heacock, H. \& Sidhu, B. (2013). ENVH 8400 Note Package. British Columbia Institute of Technology, Burnaby, BC.

Kramer, G.P., Douglas A. B., Vicky P. (2009). Introduction to clinical psychology: 7th ed. Upper Saddle River: NJ

Leedy P, Ormrod JE, Hall MP. (2001). Practical Research: planning and design, $7^{\text {th }}$ edition. 
Metro Vancouver. (2012). The Green Bin Program.

Retrieved from:

http://vancouver.ca/green-vancouver/food-scraps-

program.aspx

Metro Vancouver. (2012). Metro Vancouver's Waste to Energy Facility. Retrieved from:

http://www.metrovancouver.org/services/solidwaste/plannin g/Recover/Pages/WastetoEnergyFacility.aspx

Ministry of Environment. (1993). Landfill criteria for municipal solid waste. Retrieved from:

http://www.env.gov.bc.ca/epd/mun-waste/wastesolid/landfills/criteria-landfills.htm\#RTFToC1

Microsoft. (2007). Microsoft Excel: version 2007. Nelson, J. (2010). Waste-to-energy incineration is both noxious and expensive. CCPA Monitor, 16(8), 20-21.

Number Cruncher for Statistical Systems (NCSS). (2013). Version 9.

Ontario Ministry of Labour. (2013). Inspectors target recycling and waste hazards. Retrieved from: http://www.labour.gov.on.ca/english/news/2013/bg_recyclin gwasteblitz20131024.php

Plackett, R. L.(1983). "Karl Pearson and the Chi-Squared Test". International Statistical Review International Statistical Institute. 51 (1): 59-72.

Survey Monkey. (2013). Online Survey software. Retrieved from:

https://www.surveymonkey.com/

Sinosky, K. (2013). High levels of cadmium found in Delta landfill. Vancouver Sun. Retrieved from: http://www.vancouversun.com/technology/High+levels+cad mium+found+Delta+landfill/8874559/story.html

Standing Committee on Services and Budgets. (2010). Food Scraps collection proposed phase 2pilot. Retrieved from: http://former.vancouver.ca/ctyclerk/cclerk/20110714/docum ents/csbu1_Presentation.pdf

Statistics Canada, (2012). Population of census metropolitan areas. Retrieved from:

http://www.statcan.gc.ca/tables-tableaux/sumsom/101/cst01/demo05a-eng.htm

Suzuki, D. (2013). Incinerating trash is a waste of resources. David Suzuki Foundation Blog.

Retrieved from: http://www.davidsuzuki.org/blogs/sciencematters/2013/09/incinerating-trash-is-a-waste-of-resources/

Truong, M. (2010). Evaluating Metro Vancouver's knowledge of food scraps recycling. Research Paper.
Tucker, M. (2010). Yard Trimmings, Food Waste Composition in Vancouver. Biocycle, 51(8), 43-45.

Vancouver Annual Landfill Report. (2012). Retrieved from: http://vancouver.ca/files/cov/2012-vancouver-landfillannual-report.PDF

Walsh, B. Recycling Food Scraps. (2008). Time. 171(25):116.

Yepsen, R. (2011). Metro Vancouver Zeros in on Food Scraps Collection. Biocycle, 52(10), 32-34.

Zotos, G., Karagiannidis, A., Malamakis, A., Antonopoulo,s I., Kontogianni, S., Tchobanoglous, G. (2009). Developing a holistic strategy for integrated waste management within municipal planning: Challenges, policies, solutions and perspectives for Hellenic municipalities in the zero-waste, low-cost direction. Waste Management. 29 (5): 1686-1692 